\title{
Concise Syntheses of Coronarin A, Coronarin E, Austrochaparol and Pacovatinin A
}

\author{
Takahiro Miyake, ${ }^{a, b}$ Keisuke UdA, ${ }^{a}$ Masako Kinoshita, ${ }^{a}$ Mikio FusII ${ }^{a}$ and Hiroyuki AkitA ${ }^{*}, a$ \\ ${ }^{a}$ Faculty of Pharmaceutical Sciences, Toho University; 2-2-1 Miyama, Funabashi, Chiba 274-8510, Japan: and \\ ${ }^{b}$ Tsukuba Research Institute, Novartis Pharma Co., Ltd.; 8 Ohkubo, Tsukuba, Ibaraki 300-2611, Japan. \\ Received November 15, 2007; accepted December 13, 2007; published online December 19, 2007
}

Total syntheses of (+)-coronarin A (1), (+)-coronarin E (2), (+)-austrochaparol (3) and (+)-pacovatinin A (4) were achieved from the synthetic $(+)$-albicanyl acetate (6). Dess-Martin oxidation of $(+)$-albicanol (5) derived from the chemoenzymatic product (6) gave an aldehyde (7), which was subjected to Julia one-pot olefination using $\beta$-furylmethyl-heteroaromatic sulfones $(8$ or 9$)$ gave $(+)$-trans coronarin $E(2)$ and $(+)$-cis coronarin $E$ (12) with high cis-selectivity. The synthesis of (+)-coronarin A (1) from (+)-trans coronarin $E$ (2) was achieved, while (+)-cis coronarin E (12) was converted to the natural products $(+)-(5 S, 9 S, 10 S)-15,16-e p o x y-$ 8(17),13(16),14-labdatriene (13) and (+)-austrochaparol (3). By the asymmetric synthesis of $(+)-3$, the absolute structure of $(+)-3$ was determined to be $5 S, 7 R, 9 R, 10 S$ configurations. Homologation of (+)-albicanol (5) followed by allylic oxidation gave $(7 \alpha)$-hydroxy nitrile $(17)$, which was finally converted to the natural $(+)-$ pacovatinin $A(4)$ in 8 steps from (+)-albicanol (5).

Key words (+)-coronarin A; (+)-coronarin E; (+)-austrochaparol; (+)-pacovatinin A; total synthesis

There are many natural products possessing a labdane skeleton in nature. Among them, $(+)$-coronarin A (1),${ }^{1)}(+)$ coronarin $\mathrm{E}(\mathbf{2}){ }^{2)}(+)$-austrochaparol $(\mathbf{3})^{3)}$ and $(+)$-pacovatinin $\mathrm{A}(4)^{4)}$ are typical compounds (Chart 1). For the synthesis of these compounds, (+)-albicanol (5) is the desirable compound as starting material. We reported that lipase-assisted resolution of racemic albicanol $( \pm)-5$ gave $(+)$-albicanyl acetate $(6,56 \%, 67 \%$ ee) and (-)-albicanol $(5,38 \%$, $>99 \%$ ee) in the presence of acylating reagent. ${ }^{5)}$ Hydrolysis of $67 \%$ ee of (+)-6 gave $67 \%$ ee of (+)-albicanol (5), which was again subjected to lipase-assisted resolution to obtain the optically pure (+)-6 in 53\% yield. This chemoenzymatic procedure was found to be effective for procurement as starting material for the synthesis of chiral decaline type sesquiterpenoids and diterpenoids. Herein we report the concise synthesis of $(+)$-coronarin A (1), (+)-coronarin E (2), $(+)$-austrochaparol (3) and (+)-pacovatinin A (4) from (+)albicanyl acetate $(6)$.

Synthesis of (+)-Coronarin A (1), (+)-Coronarin E (2) and (+)-Austrochaparol (3) The furanolabdane diterpenoids, coronarin A (1) and coronarin E (2), are isolated from rhizomers of the Brazilian antirheumatic medicinal plant, Hedychium Coronarium (Zingiberaceae). ${ }^{1,2)}$ These compounds exhibit a significant cytotoxic effect against Chinese hamster V-79 cells and sarcoma 180 ascites in mice. ${ }^{1)}$
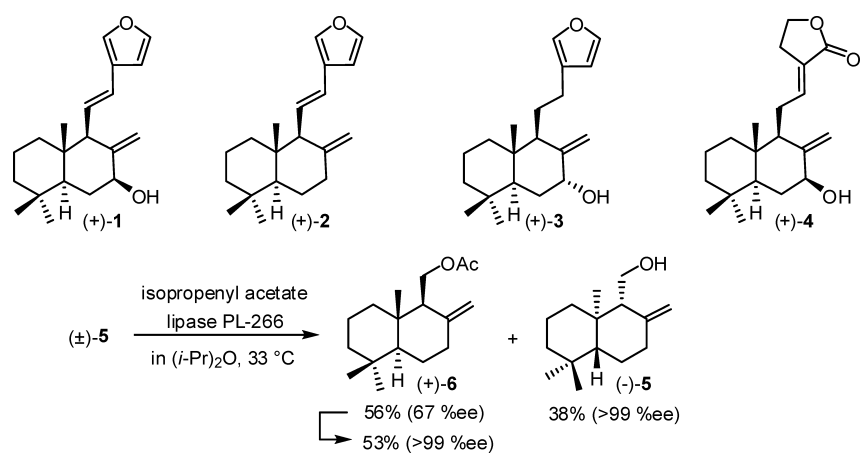

Chart 1
The structures of these compounds are established by chemical and spectroscopic methods. The absolute structure of $\mathbf{1}$ was determined based on the allyic benzoate rule, because the $p$-bromobenzoate of $\mathbf{1}$ showed a positive cotton curve at $245 \mathrm{~nm} .{ }^{1)}(+)$-Austrochaparol (3) is isolated from the aerial parts of Austroeupatorium chaparense and its absolute structure has not been determined yet. ${ }^{3)}$ The synthesis of $(+)-1$ was achieved from natural product, $(+)$-sclareolide in ten steps. ${ }^{6)}$ For the synthesis of these compounds, carbon-carbon bond formation between an aldehyde (7) and $\beta$-furylmethyl unit sulfone $\mathbf{A}$ or phosphonium salt $\mathbf{B}$ is necessary as shown in Chart 2.

The aldehyde (7) could be derived from the present enzymatic product (6). Wittig reaction of 7 and phosphonium salt B was reported to give $\mathbf{2}$ in $32 \%$ yield. ${ }^{7)}$ To overcome the low yield of this carbon-carbon bond formation process, one-pot Julia coupling ${ }^{8)}$ of 7 and heteroaromatic sulfone A (8 or 9 ) possessing $\beta$-furylmethyl moiety was carried out. The straightforward synthesis of these compounds from $(+)$-albicanyl acetate (6) is shown in Chart 3.

The synthesis of the desired sulfone $\mathbf{A}$ was shown in Chart 3 . The reaction of 3-furylmethanol with 2-mercaptobenzothiazole (BTSH) or 1-phenyl-1 $H$-tetrazol-5-thiol (PTSH) in the presence of triphenylphosphine $\left(\mathrm{Ph}_{3} \mathrm{P}\right)$ and diethylazodicarboxylate (DEAD) gave sulfides $(\mathbf{1 0}, 91 \%$ yield) or $(\mathbf{1 1}$, $91 \%$ yield), which was separately oxidized with $m$-chloroperbenzoic acid ( $m$-CPBA) to afford sulfones $(8,67 \%$ yield) or $(\mathbf{9}, 31 \%$ yield), respectively. Treatment of $(+)$-albicanyl acetate (6) with $\mathrm{K}_{2} \mathrm{CO}_{3}$ gave (+)-albicanol (5) in quantitative yield, which was treated with Dess-Martin reagent to afford

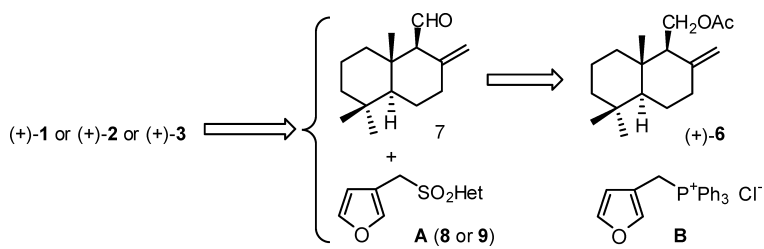

Chart 2 

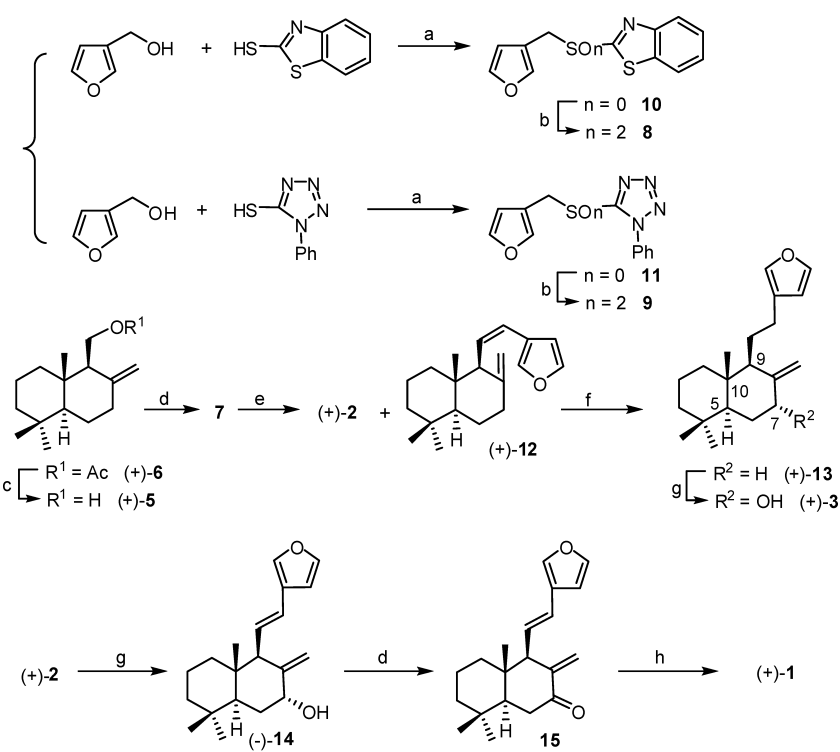

Reagents: (a) $\mathrm{Ph}_{3} \mathrm{P} / \mathrm{EtOOC}-\mathrm{N}=\mathrm{N}-\mathrm{COOEt} / \mathrm{THF}$ (b) $m$-CPBA $/ \mathrm{CH}_{2} \mathrm{Cl}_{2}$ (c) $\mathrm{K}_{2} \mathrm{CO}_{3} / \mathrm{MeOH}$ (d) Dess-Martin reagent $/ \mathrm{NaHCO}_{3} / \mathrm{CH}_{2} \mathrm{Cl}_{2}$ (e) $8 / \mathrm{LiN}(\mathrm{TMS})_{2} / \mathrm{THF}$ or $9 / \mathrm{KN}(\mathrm{TMS})_{2} / \mathrm{DME}$ (f) $\mathrm{H}_{2} / \mathrm{Pd}-\mathrm{BaSO}_{4} /$ quinoline (g) $\mathrm{SeO}_{2} / \mathrm{CH}_{2} \mathrm{Cl}_{2}$ (h) $\mathrm{NaBH}_{4} / \mathrm{MeOH}$

\section{Chart 3}

the aldehyde (7) in $83 \%$ yield. The Julia one-pot olefination between an aldehyde (7) and sulfone (8) in the presence of lithium bis(trimethylsilylamide) gave $(+)$-coronarin $\mathrm{E}(\mathbf{2}$, $11 \%$ yield) and $(+)$-cis-coronarin $\mathrm{E}\left(\mathbf{1 2}, 77 \%\right.$ yield, $[\alpha]_{\mathrm{D}}^{23}$ $\left.+109.1^{\circ}\left(c=0.44, \mathrm{CHCl}_{3}\right)\right)$. The physical data $\left([\alpha]_{\mathrm{D}}^{20}+22.4^{\circ}\right.$ $\left(c=1.40, \mathrm{CHCl}_{3}\right)$ and $\left.{ }^{1} \mathrm{H}-\mathrm{NMR}\right)$ of the synthetic $(+)-2$ were identical with those $\left([\alpha]_{\mathrm{D}}+22.3^{\circ}\left(c=0.44, \mathrm{CHCl}_{3}\right)\right.$ and ${ }^{1} \mathrm{H}$ NMR $)^{2)}$ of the natural $(+)-2$. The ${ }^{1} \mathrm{H}-\mathrm{NMR}$ data of the synthetic $(+)-12$ were in agreement with those of the reported $(+)-12$ derived from natural $(-)$-sclareol. ${ }^{9}$ When the reaction conditions (sulfone $\mathbf{8}$ or $\mathbf{9}$, base, solvent) were changed for the purpose of improvement of ratio of trans- $(+)-2$, the results were as shown in Table 1 (entries $1-5)$. High $c i s$-selectivity was observed in every case.

Hydrogenation of the main cis- $(+)-\mathbf{1 2}$ in the presence of quinoline and $5 \% \mathrm{Pd}-\mathrm{BaSO}_{4}$ gave compound $(+)-\mathbf{1 3}(86 \%$ yield, $\left.[\alpha]_{\mathrm{D}}^{23}+44.1^{\circ}\left(c=0.59, \mathrm{CHCl}_{3}\right)\right)$, which was in accord with the reported natural product $(+)-(5 S, 9 S, 10 S)-15,16-$ epoxy-8(17),13(16),14-labdatriene $\left(\mathbf{1 3},[\alpha]_{\mathrm{D}}^{26}+49.3^{\circ}(c=1.00\right.$, $\left.\left.\mathrm{CHCl}_{3}\right)\right) .{ }^{10)}$ Allylic oxidation of $(+)-\mathbf{1 3}$ with $\mathrm{SeO}_{2}$ gave $(+)$ austrochaparol $\left(3,50 \%\right.$ yield, $\left.[\alpha]_{\mathrm{D}}^{27}+5.6^{\circ}\left(c=0.50, \mathrm{CHCl}_{3}\right)\right)$. The physical data $\left([\alpha]_{\mathrm{D}}\right.$ and $\left.{ }^{1} \mathrm{H}-\mathrm{NMR}\right)$ of the synthetic $(+)-3$ were identical with those $\left([\alpha]_{\mathrm{D}}^{24}+8.5^{\circ}\left(c=6.11, \mathrm{CHCl}_{3}\right)\right.$ and ${ }^{1} \mathrm{H}-\mathrm{NMR}$ ) of natural $3 .{ }^{3)}$ Consequently, absolute configurations of natural 3 were confirmed to be $5 S, 7 R, 9 R, 10 S$. Generation of $7 \alpha$-hydroxy compound (3) could be explained by an attack of the reagent from the less-hindered $\alpha$-side. Moreover, allylic oxidation of (+)-2 with $\mathrm{SeO}_{2}$ afforded (-)-epicoronarin A $\left(\mathbf{1 4}, 47 \%\right.$ yield, $\left.[\alpha]_{\mathrm{D}}^{23}-13.4^{\circ}\left(c=1.16, \mathrm{CHCl}_{3}\right)\right)$, which was subjected to oxidation with Dess-Martin reagent to give a $\alpha, \beta$-unsaturated ketone (15). $\mathrm{NaBH}_{4}$ reduction of 15 gave $(+)$-coronarin $\mathrm{A}\left[\left(\mathbf{1}, \mathrm{mp} 99-101^{\circ} \mathrm{C},[\alpha]_{\mathrm{D}}^{23}+26.9^{\circ}\right.\right.$ $\left.\left(c=0.35, \mathrm{CHCl}_{3}\right)\right]$ in $78 \%$ yield from $(+)-14$. The physical data of the synthetic $(+)-1$ were identical with those $(\mathrm{mp}$ $100-101^{\circ} \mathrm{C},[\alpha]_{\mathrm{D}}+25.4^{\circ}\left(c=0.28, \mathrm{CHCl}_{3}\right)$ and $\left.{ }^{1} \mathrm{H}-\mathrm{NMR}\right)^{1)}$ of the natural $(+)-1$.

Synthesis of Pacovatinin A (4) Pacovatinin A (4) was
Table 1. Stereoselectivity by One-Pot Julia Coupling

\begin{tabular}{|c|c|c|c|c|c|}
\hline Entry & $\begin{array}{l}\text { Hetero-sulfone } \\
\qquad(\mathbf{8} \text { or } \mathbf{9})\end{array}$ & Base & Solvent & $\begin{array}{l}\text { Yield } \\
(\%)\end{array}$ & cis-12 : trans-2 \\
\hline 1 & 8 & $\mathrm{LiN}(\mathrm{TMS})_{2}$ & THF & 88 & $87: 13$ \\
\hline 2 & 8 & $\mathrm{NaN}(\mathrm{TMS})_{2}$ & THF & 74 & $88: 12$ \\
\hline 3 & 8 & $\mathrm{KN}(\mathrm{TMS})_{2}$ & THF & 75 & $91: 9$ \\
\hline 4 & 8 & $\mathrm{KN}(\mathrm{TMS})_{2}$ & DME & 86 & $97: 3$ \\
\hline 5 & 9 & $\mathrm{KN}(\mathrm{TMS})_{2}$ & DME & 73 & $98: 2$ \\
\hline
\end{tabular}

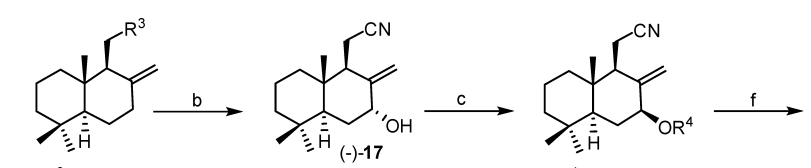

- $\mathrm{R}^{3}=\mathrm{OH} \quad(+)-5$

$\longrightarrow \mathrm{R}^{3}=\mathrm{CN}(+)-16$
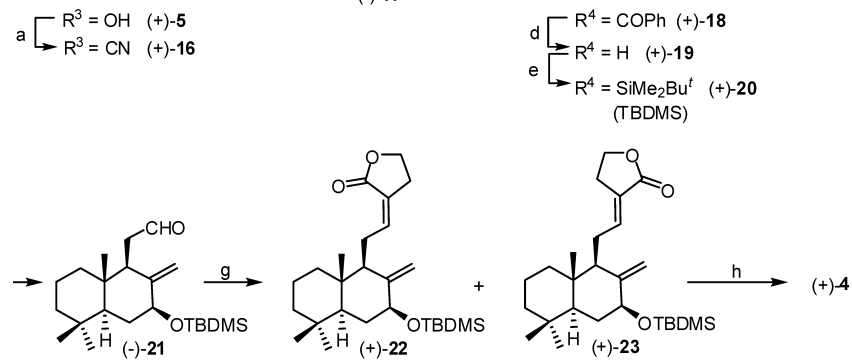

Reagents: (a) $\mathrm{Me}_{2} \mathrm{C}(\mathrm{OH}) \mathrm{CN} / \mathrm{Ph}_{3} \mathrm{P} /{ }^{i} \mathrm{PrOOC}-\mathrm{N}=\mathrm{N}-\mathrm{COOPr}^{i}$ (b) $\mathrm{SeO}_{2} /{ }^{t} \mathrm{BuOOH} / \mathrm{CH}_{2} \mathrm{Cl}_{2}$ (c) $\mathrm{PhCOOH} / \mathrm{Ph}_{3} \mathrm{P} / \mathrm{EtOOC}-\mathrm{N}=\mathrm{N}-\mathrm{COOEt}$ (d) $\mathrm{K}_{2} \mathrm{CO}_{3} / \mathrm{MeOH}$ (e) ${ }^{t} \mathrm{BuMe}_{2} \mathrm{SiCl} /$ imidazole / DMF (f) $\mathrm{HAl}(i-\mathrm{Bu})_{2} /$ toluene (g) diethoxyphosphonobutyrolactone / ${ }^{t} \mathrm{BuOK} / \mathrm{DMSO}$ (h) $\mathrm{CSA} / \mathrm{MeOH}$

Chart 4

isolated from seeds of the Brazilian medicinal plant, $R e$ nealmia exaltata L.f. (Zingiberaceae), and its structure including absolute configurations was elucidated by spectroscopic analysis and a modified Mosher method. ${ }^{4)}$ On the other hand, hedychilactone A (4) was isolated from the methanolic extract of the fresh rhizome of Hedychium coronarium KoENG, and found to inhibit the increase of vascular permeability induced by acetic acid in mice and nitric oxide production in lipopolysaccharide-activated mouse peritoneal macrophages. ${ }^{11,12)}$ Interestingly, hedychilactone A has been already reported under a different name, pacovatinin A (4). The straightforward synthesis of $(+)-\mathbf{4}$ from $(+)-5$ is shown in Chart 4.

Homologation of (+)-5 was accomplished by displacement of the hydroxyl group with cyanide under Mitsunobu conditions ${ }^{13,14)}$ in the presence of acetone cyanohydrin to give nitrile 16 in $64 \%$ yield. ${ }^{1} \mathrm{H}$ - and ${ }^{13} \mathrm{C}-\mathrm{NMR}$ data of the synthetic 16 were identical with those of the reported $(+)-\mathbf{1 6}$ by us. ${ }^{15)}$ Allylic oxidation of $\mathbf{1 6}$ using a combination of $\mathrm{SeO}_{2}$ and tert-BuOOH gave the $7 \alpha$-hydroxy compound (17) in $79 \%$ yield. Stereochemical inversion of $7 \alpha$-configuration to $7 \beta$-configuration was achieved by the Mitsunobu method. ${ }^{16)}$ Treatment of 17 with benzoic acid in the presence of $\mathrm{Ph}_{3} \mathrm{P}$ and diethylazodicarboxylate (DEAD) afforded $7 \beta$-acyloxy nitrile (18,79\% yield), which was treated with $\mathrm{K}_{2} \mathrm{CO}_{3}$ in $\mathrm{MeOH}$ to provide $6 \beta$-alcohol (19) in $78 \%$ yield. Silylation of the secondary alcohol group of $\mathbf{1 9}$ followed by Dibal reduction gave an aldehyde (21) in overall $84 \%$ yield (2 steps from 19). Horner-Emmons condensation of 21 and diethoxyphosphonobutyrolactone in the presence of tert-BuOK gave the less polar compound (22, 27\% yield) and the more polar one (23, 63\% yield). Deprotection of silyl group of $\mathbf{2 3}$ provided $(+)-4\left[[\alpha]_{\mathrm{D}}^{24}+12.8^{\circ}\left(c=1.0, \mathrm{CHCl}_{3}\right), 92 \%\right.$ yield $]$, of which 


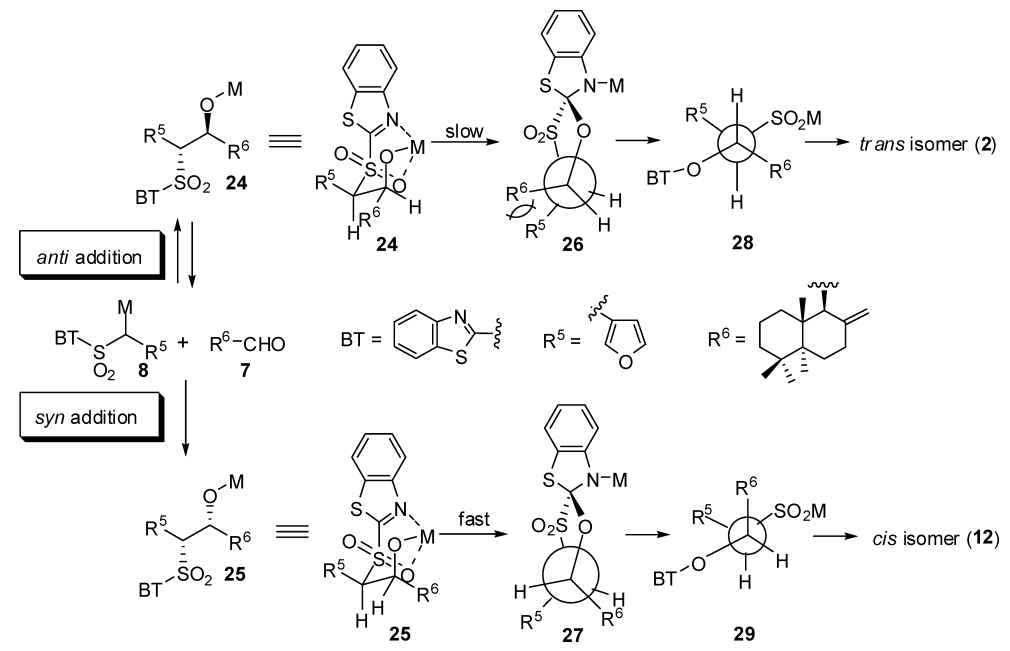

Chart 5. Proposed Mechanism for the One-Pot Julia Olefination

spectral data $\left({ }^{1} \mathrm{H}\right.$ - and $\left.{ }^{13} \mathrm{C}-\mathrm{NMR}\right)$ were identical with those of the reported $\left.(+)-4\left[[\alpha]_{\mathrm{D}}^{23}+10.0^{\circ}\left(c=1.00, \mathrm{CHCl}_{3}\right)\right] .^{4}\right)$

\section{Discussion}

Julia one-pot olefination between aldehyde (7) and BT-sulfone (8) gave (+)-cis-coronain E (12) with high cis-selectivity. This high selectivity could be explained as shown in Chart 5.

Metallated BT-sulfone (8) condenses with aldehyde (7) to give anti isomer (24) and syn isomer (25), which are converted to intermediates $\mathbf{2 6}$ and 27, respectively. Direct loss of lithio-benzothiazolone and sulfur dioxide from intermediates $\mathbf{2 6}$ and $\mathbf{2 7}$ may yield trans isomer (2) via $\mathbf{2 8}$ and cis isomer (12) via 29, respectively. The energy barrier to Smiles rearrangement for the anti isomer (24) is presumably higher than that for the corresponding syn isomer (25) due to the eclipsed/gauche arrangement of $\mathrm{R}^{5}$ and $\mathrm{R}^{6}$ in the appropriate transition state for spirocyclisation. Therefore, the formation rate of $\mathbf{2 6}$ from $\mathbf{2 4}$ may be slow, while that of $\mathbf{2 7}$ from $\mathbf{2 5}$ may be fast. The possibility of addition/retroaddition in the reaction of metallated BT-sulfone with aldehyde has been established experimentally. ${ }^{7)}$ Equilibration between 24 and 25 together with faster Smiles rearrangement/elimination for the latter provide a reasonable explanation for the high cis-selectivity.

\section{Conclusion}

Total syntheses of $(+)$-coronarin A (1), $(+)$-coronarin E (2), (+)-austrochaparol (3) and (+)-pacovatinin A (4) were achieved from $(+)$-albicanyl acetatel $(6)$, which was effectively obtained based on the enzymatic resolution of $( \pm)-\mathbf{5}$. Dess-Martin oxidation of $(+)$-albicanol (5) derived from $(+)-6$ gave an aldehyde (7), which was subjected to Julia one-pot olefination using $\beta$-furylmethyl-heteroaromatic sulfones $(\mathbf{8}$ or 9) gave (+)-trans coronarin E (2) and (+)-cis coronarin E (12) with high cis-selectivity. Allylic oxidation of (+)-trans coronarin $\mathrm{E}(2)$ followed by consecutive oxidation and $\mathrm{NaBH}_{4}$ reduction gave (+)-coronarin $\mathrm{A}(\mathbf{1})$. Partial reduction of $(+)$-cis coronarin $\mathrm{E}(\mathbf{1 2})$ provided $(+)-(5 S$, 9S,10S)-15,16-epoxy-8(17),13(16),14-labdatriene (13), which was subjected to allylic oxidation to provide (+)-austrochaparol (3). Consequently, absolute configurations of natural $\mathbf{3}$ were confirmed to be $5 S, 7 R, 9 R, 10 S$. Homologation of albicanol (+)-5 followed by allylic oxidation gave $(7 \alpha)$-hydroxy nitrile 17 , which was subjected to the Mitsunobu reaction to provide the desired $(7 \beta)$-acyloxy nitrile 18. This compound was converted to the $(7 \beta)$-siloxy aldehyde 21 , which was subjected to the Horner-Emmons reaction to afford the desired trans $\gamma$-lactone 23. Deprotection of the silyl group of 23 gave the natural (+)-pacovatinin A (4) in $15 \%$ overall yield (8 steps) from (+)-albicanol (5).

\section{Experimental}

All melting points were measured on a Yanaco MP-3S micro melting point apparatus and are uncorrected. ${ }^{1} \mathrm{H}-\mathrm{NMR}$ spectra were recorded on a JEOL EX 400 spectrometer. Spectra were taken with 5-10\% (w/v) solution in $\mathrm{CDCl}_{3}$ with $\mathrm{Me}_{4} \mathrm{Si}$ as an internal reference. The mass spectra, $\mathrm{FAB}$ and EI, were obtained with a JEOL JMS-600 H (matrix; glycerol, $m$-nitrobenzyl alcohol) or a JEOL JMS-AM II 50 spectrometer, respectively. IR spectra were recorded on a JASCO FT/IR-300 spectrometer. Optical rotations were measured with a JASCO DIP-370 digital polarimeter. All evaporations were performed under reduced pressure. For column chromatography, silica gel (Kieselgel 60) was employed.

3-Furylmethyl Benzothiazol-2-yl Sulfide (10) To a solution of 3-furylmethanol $(3.01 \mathrm{~g}, 30.6 \mathrm{mmol})$ in THF $(70 \mathrm{ml})$ was added 2-mercaptobenzothiazole $(10.2 \mathrm{~g}, 61.2 \mathrm{mmol}), \mathrm{Ph}_{3} \mathrm{P}(16.0 \mathrm{~g}, 61.2 \mathrm{mmol})$ and $2.2 \mathrm{M}$ diethylazodicarboxylate (DEAD) in toluene solution $(28 \mathrm{ml}, 61.2 \mathrm{mmol})$ at $0{ }^{\circ} \mathrm{C}$ and the whole mixture was stirred under argon atmosphere for $14 \mathrm{~h}$ at room temperature (rt). The reaction mixture was diluted with $2 \mathrm{M}$ aqueous $\mathrm{NaOH}$ and extracted with $\mathrm{Et}_{2} \mathrm{O}$. The organic layer was washed with brine, and dried over $\mathrm{MgSO}_{4}$. The organic layer was evaporated to give a crude residue, which was chromatographed on silica gel $(150 \mathrm{~g}, n$-hexane : AcOEt $=100: 1)$ to afford $\mathbf{1 0}(6.90 \mathrm{~g}, 91 \%)$ as a pale yellow oil. 10: IR (neat): 3126, 3062, $1503 \mathrm{~cm}^{-1}$; ${ }^{1} \mathrm{H}-\mathrm{NMR} \delta$ : $4.42(2 \mathrm{H}$, br s) $6.44(1 \mathrm{H}$, br s), $7.28(1 \mathrm{H}, \mathrm{ddd}$, $J=9.0,7.2,1.2 \mathrm{~Hz}), 7.35(1 \mathrm{H}, \mathrm{brs}), 7.41(1 \mathrm{H}, \mathrm{ddd}, J=8.0,7.2,1.2 \mathrm{~Hz}), 7.47$ $(1 \mathrm{H}, \mathrm{m}), 7.74(1 \mathrm{H}$, ddd, $J=9.0,1.2,0.8 \mathrm{~Hz}), 7.88(1 \mathrm{H}, \mathrm{ddd}, J=9.0,1.2$, $0.8 \mathrm{~Hz}) .{ }^{13} \mathrm{C}-\mathrm{NMR} \delta: 28.0,111.0,120.3,121.0,121.5,124.3,126.1,135.3$, 141.1, 143.3, 153.0, 166.2. Anal. Calcd for $\mathrm{C}_{12} \mathrm{H}_{9} \mathrm{NOS}_{2}$ : C, 58.27; H, 3.67; $\mathrm{N}$, 5.66. Found: C, 58.36; H, 3.86; N, 5.31. HR-MS (EI) Calcd for $\mathrm{C}_{12} \mathrm{H}_{9} \mathrm{NOS}_{2}: 247.0126$. Found: 247.0127 .

3-Furylmethyl Benzothiazol-2-yl Sulfone (8) To a solution of $\mathbf{1 0}$ $(10.67 \mathrm{~g}, 43.1 \mathrm{mmol})$ in $\mathrm{CH}_{2} \mathrm{Cl}_{2}(200 \mathrm{ml})$ was added $m$-chloroperbenzoic acid $(m$-CPBA; $27.96 \mathrm{~g}, 129 \mathrm{mmol})$ at $0{ }^{\circ} \mathrm{C}$ and the whole mixture was stirred for $2 \mathrm{~h}$ at $\mathrm{rt}$. The reaction mixture was diluted with $2 \mathrm{~m}$ aqueous $\mathrm{NaOH}$ and extracted with $\mathrm{CH}_{2} \mathrm{Cl}_{2}$. The organic layer was washed with brine, and dried over $\mathrm{MgSO}_{4}$. The organic layer was evaporated to give a crude residue, which was chromatographed on silica gel (200g, nhexane : $\mathrm{AcOEt}=10: 1)$ to afford $\mathbf{8}(8.08 \mathrm{~g}, 67 \%)$ as colorless needles. $8: \mathrm{mp}$ $134-136^{\circ} \mathrm{C}$ (colorless needles from $n$-hexane-AcOEt); IR (KBr): 3141 , $1555,1504 \mathrm{~cm}^{-1}$; ${ }^{1} \mathrm{H}-\mathrm{NMR} \delta: 4.62(2 \mathrm{H}, \mathrm{brs}), 6.35(1 \mathrm{H}, \mathrm{brs}), 7.34-7.36$ $(2 \mathrm{H}, \mathrm{m}), 7.59(1 \mathrm{H}, \mathrm{ddd}, J=8.0,7.2,1.2 \mathrm{~Hz}), 7.64(1 \mathrm{H}, \mathrm{ddd}, J=8.0,7.2,1.2$ 
$\mathrm{Hz}), 7.97(1 \mathrm{H}$, ddd, $J=8.0,1.2,0.8 \mathrm{~Hz}), 8.24(1 \mathrm{H}$, ddd, $J=8.0,1.2,0.8 \mathrm{~Hz})$ ${ }^{13} \mathrm{C}-\mathrm{NMR} \delta$ : $51.7,111.1,111.5,122.3,125.4,127.7,128.0,136.9,143.4$ 143.8, 152.5, 165.0. Anal. Calcd for $\mathrm{C}_{12} \mathrm{H}_{9} \mathrm{NO}_{2} \mathrm{~S}_{2}: \mathrm{C}, 51.60 ; \mathrm{H}, 3.25 ; \mathrm{N}$, 5.01. Found: C, 51.73; H, 3.37; N, 4.59.

3-Furylmethyl 1-Phenyl-1H-tetrazol-5-yl Sulfide (11) To a solution of 3-furylmethanol $(1.00 \mathrm{~g}, 10.2 \mathrm{mmol})$ in THF $(20 \mathrm{ml})$ was added 1-phenyl$1 H$-tetrazol-5-thiol $(3.65 \mathrm{~g}, 20.5 \mathrm{mmol}), \mathrm{Ph}_{3} \mathrm{P}(5.36 \mathrm{~g}, 20.4 \mathrm{mmol})$ and $2.2 \mathrm{M}$ diethylazodicarboxylate (DEAD) in toluene solution $(7.0 \mathrm{ml}, 15.4 \mathrm{mmol})$ at $0{ }^{\circ} \mathrm{C}$ and the whole mixture was stirred under argon atmosphere for $3 \mathrm{~h}$ at $\mathrm{rt}$. The reaction mixture was diluted with $2 \mathrm{M}$ aqueous $\mathrm{NaOH}$ and extracted with $\mathrm{Et}_{2} \mathrm{O}$. The organic layer was washed with brine, and dried over $\mathrm{MgSO}_{4}$ The organic layer was evaporated to give a crude residue, which was chromatographed on silica gel $(100 \mathrm{~g}, n$-hexane : AcOEt $=30: 1)$ to afford 11 $(2.38 \mathrm{~g}, 91 \%)$ as a pale yellow oil. 11: IR (neat): $3137,3068,1595,1499$ $\mathrm{cm}^{-1} ;{ }^{1} \mathrm{H}-\mathrm{NMR} \delta: 4.48(2 \mathrm{H}, \mathrm{s}), 6.23(1 \mathrm{H}, \mathrm{dd}, J=1.6,0.4 \mathrm{~Hz}), 7.36(1 \mathrm{H}, \mathrm{dd}$ $J=1.6,1.6 \mathrm{~Hz}), 7.51-7.55(6 \mathrm{H}, \mathrm{m}) .{ }^{13} \mathrm{C}-\mathrm{NMR} \delta: 27.9,110.7,119.4,123.7$ (2C), 129.7 (2C), 130.1, 133.5, 141.4, 143.4, 153.7. HR-MS (EI) Calcd for $\mathrm{C}_{12} \mathrm{H}_{10} \mathrm{~N}_{4} \mathrm{OS}$ : 258.0565. Found: 258.0575.

3-Furylmethyl 1-Phenyl-1H-tetrazol-5-yl Sulfone (9) To a solution of $11(0.201 \mathrm{~g}, 0.779 \mathrm{mmol})$ in $\mathrm{CH}_{2} \mathrm{Cl}_{2}(3.5 \mathrm{ml})$ was added $m$-chloroperbenzoic acid ( $m$-CPBA; $0.836 \mathrm{~g}, 4.84 \mathrm{mmol})$ at $0{ }^{\circ} \mathrm{C}$ and the whole mixture was stirred for $15 \mathrm{~h}$ at $\mathrm{rt}$. The reaction mixture was diluted with $2 \mathrm{M}$ aqueous $\mathrm{NaOH}$ and extracted with $\mathrm{CH}_{2} \mathrm{Cl}_{2}$. The organic layer was washed with brine, and dried over $\mathrm{MgSO}_{4}$. The organic layer was evaporated to give a crude residue, which was chromatographed on silica gel $(200 \mathrm{~g}, n$ hexane : $\mathrm{AcOEt}=5: 1)$ to afford $9(0.069 \mathrm{~g}, 31 \%)$ as colorless needles. 9: $\mathrm{mp}$ $138-140{ }^{\circ} \mathrm{C}$ (colorless needles from $n$-hexane-AcOEt); IR (KBr): 3121 , $3070,1601,1497 \mathrm{~cm}^{-1} ;{ }^{1} \mathrm{H}-\mathrm{NMR} \delta: 4.84(2 \mathrm{H}, \mathrm{s}), 6.43(1 \mathrm{H}, \mathrm{dd}, J=2.0,0.8$ $\mathrm{Hz}), 7.40(1 \mathrm{H}, \mathrm{dd}, J=1.6,1.6 \mathrm{~Hz}), 7.48-7.63(6 \mathrm{H}, \mathrm{m}) .{ }^{13} \mathrm{C}-\mathrm{NMR} \delta: 53.3$, 109.7, 111.7, 125.1 (2C), 129.5 (2C), 131.4, 132.8, 143.9, 144.2, 152.7 Anal. Calcd for $\mathrm{C}_{12} \mathrm{H}_{10} \mathrm{~N}_{4} \mathrm{O}_{3} \mathrm{~S}$ : C, 49.65; H, 3.47; N, 19.30. Found: C, 49.85; H, 3.58; N, 19.48

(+)-trans-Coronarin $\mathbf{E}(2)$ and (+)-cis-Coronarin $\mathbf{E}(12)$ 1) A suspension of $(+)-6(4.50 \mathrm{~g}, 17.0 \mathrm{mmol})$ and $\mathrm{K}_{2} \mathrm{CO}_{3}(8.36 \mathrm{~g}, 60.5 \mathrm{mmol})$ in $\mathrm{MeOH}(50.0 \mathrm{ml})$ was stirred for $12 \mathrm{~h}$ at $\mathrm{rt}$. The reaction mixture was evaporated, diluted with saturated brine and extracted with $\mathrm{Et}_{2} \mathrm{O}$. The organic layer was dried over $\mathrm{MgSO}_{4}$ and evaporated to afford a crude product which was chromatographed on silica gel $(100.0 \mathrm{~g})$ to give $(+)-5(3.78 \mathrm{~g}, 99 \%$ yield from $n$-hexane : $\mathrm{AcOEt}=30: 1$ eluent. $(+)-5: \mathrm{mp} 71-73{ }^{\circ} \mathrm{C}$ (colorless needles from $n$-hexane), $[\alpha]_{\mathrm{D}}^{24}+10.8^{\circ}\left(c=0.5, \mathrm{CHCl}_{3}\right.$, corresponds to $>98 \%$ ee), ${ }^{1} \mathrm{H}-\mathrm{NMR}$ data of $(+)-\mathbf{5}$ were identical with those of the reported $(+)$ 5. ${ }^{10}$ Anal. Calcd for $\mathrm{C}_{15} \mathrm{H}_{22} \mathrm{O}: \mathrm{C}, 81.02 ; \mathrm{H}, 11.79$. Found: $\mathrm{C}, 81.19 ; \mathrm{H}, 11.97$. 2) To a solution of $(+)-5(1.00 \mathrm{~g}, 4.49 \mathrm{mmol})$ in $\mathrm{CH}_{2} \mathrm{Cl}_{2}(65.0 \mathrm{ml})$ was added $\mathrm{NaHCO}_{3}(5.89 \mathrm{~g}, 70.1 \mathrm{mmol})$ and Dess-Martin reagent $(3.15 \mathrm{~g}, 7.43 \mathrm{mmol})$ at $0{ }^{\circ} \mathrm{C}$ and the reaction mixture was stirred for $2 \mathrm{~h}$ at $\mathrm{rt}$. The reaction mixture was directly subjected to chromatography on silica gel $(100 \mathrm{~g}, n$ hexane : $\mathrm{AcOEt}=200: 1)$ to give $7(0.823 \mathrm{~g}, 83 \%$ yield $)$ as a colorless oil. 7 ; ${ }^{1} \mathrm{H}-\mathrm{NMR}\left(\mathrm{CDCl}_{3}\right) \delta: 0.87(3 \mathrm{H}, \mathrm{s}), 0.89(3 \mathrm{H}, \mathrm{s}), 1.03(1 \mathrm{H}, \mathrm{dd}, J=12.6,2.8$ $\mathrm{Hz}), 1.15(3 \mathrm{H}, \mathrm{s}), 1.17-1.28(2 \mathrm{H}, \mathrm{m}), 1.38-1.50(3 \mathrm{H}, \mathrm{m}), 1.54-1.66(2 \mathrm{H}$, $\mathrm{m}), 1.69-1.75(1 \mathrm{H}, \mathrm{m}), 2.05-2.13(1 \mathrm{H}, \mathrm{m}), 2.37-2.49(2 \mathrm{H}, \mathrm{m}), 4.50(1 \mathrm{H}$ br s), $4.92\left(1 \mathrm{H}\right.$, br s), $9.87(1 \mathrm{H}, \mathrm{d}, J=4.8 \mathrm{~Hz}) .{ }^{13} \mathrm{C}-\mathrm{NMR} \delta: 16.0,18.7,21.9$ $23.1,33.4,33.5,36.7,39.0,39.9,41.9,54.0,67.9,109.2,145.0,205.7 .3)$ To a solution of $8(1.14 \mathrm{~g}, 4.09 \mathrm{mmol})$ in THF $(15.0 \mathrm{ml})$ was added $1.0 \mathrm{M}$ solution of lithium bis(trimethylsilylamide) in toluene $(4.10 \mathrm{ml}, 4.10 \mathrm{mmol})$ at $-78^{\circ} \mathrm{C}$ under argon atmosphere. After being stirred at $-78^{\circ} \mathrm{C}$ for $20 \mathrm{~min}, 7$ $(0.819 \mathrm{~g}, 3.72 \mathrm{mmol})$ in THF $(5 \mathrm{ml})$ was slowly added. The mixture was stirred for $0.5 \mathrm{~h}$ at $-78^{\circ} \mathrm{C}$. The reaction was diluted with brine and extracted with $\mathrm{Et}_{2} \mathrm{O}$. The organic layer was washed with brine and dried over $\mathrm{MgSO}_{4}$ The organic layer was evaporated to give a crude residue, which was chromatographed on silica gel $(100 \mathrm{~g}, n$-hexane) to afford $(+)-\mathbf{1 2}(0.814 \mathrm{~g}, 77 \%)$ and $(+)-2(0.116 \mathrm{~g}, 11 \%)$ in elution order.

(+)-12 (Colorless Oil): $[\alpha]_{\mathrm{D}}^{23}+109.1^{\circ}\left(c=0.44, \mathrm{CHCl}_{3}\right)$. IR (neat): 1644 $\mathrm{cm}^{-1} .{ }^{1} \mathrm{H}-\mathrm{NMR}\left(\mathrm{CDCl}_{3}\right) \delta: 0.84(3 \mathrm{H}, \mathrm{s}), 0.86(3 \mathrm{H}, \mathrm{s}), 0.87(3 \mathrm{H}, \mathrm{s}), 0.91-$ $0.95(1 \mathrm{H}, \mathrm{m}), 1.11(1 \mathrm{H}, \mathrm{dd}, J=12.5,2.8 \mathrm{~Hz}), 1.14-1.22(1 \mathrm{H}, \mathrm{m}), 1.35$ $1.42(3 \mathrm{H}, \mathrm{m}), 1.47-1.54(1 \mathrm{H}, \mathrm{m}), 1.55-1.57(1 \mathrm{H}, \mathrm{m}), 1.70-1.72(1 \mathrm{H}, \mathrm{m})$, $2.06-2.14(1 \mathrm{H}, \mathrm{m}), 2.50(1 \mathrm{H}, \mathrm{ddd}, J=13.4,4.4,2.3 \mathrm{~Hz}), 2.81(1 \mathrm{H}, \mathrm{d}, J=$ $10.0 \mathrm{~Hz}), 4.61(1 \mathrm{H}, \mathrm{dd}, J=3.7,2.0 \mathrm{~Hz}), 4.75(1 \mathrm{H}, \mathrm{dd}, J=3.7,2.0 \mathrm{~Hz}), 5.62$ $(1 \mathrm{H}, \mathrm{dd}, J=11.8,9.4 \mathrm{~Hz}), 6.32(1 \mathrm{H}, \mathrm{d}, J=12.0 \mathrm{~Hz}), 6.34(1 \mathrm{H}, \mathrm{t}, J=1.2 \mathrm{~Hz})$ $7.32(1 \mathrm{H}, \mathrm{t}, J=1.2 \mathrm{~Hz}), 7.34(1 \mathrm{H}, \mathrm{t}, J=1.2 \mathrm{~Hz}) .{ }^{13} \mathrm{C}-\mathrm{NMR} \delta: 14.3,19.0$, $21.9,23.4,33.4(2 \mathrm{C}), 36.4,39.0,39.9,42.1,54.9,57.0,108.4,111.0,120.7$ 122.2, 130.0, 140.7, 142.4, 148.0. HR-MS (EI) Calcd for $\mathrm{C}_{20} \mathrm{H}_{28} \mathrm{O}_{2}$ : 284.2140. Found: 284.2145 . (+)-2: $\mathrm{mp} 94-96{ }^{\circ} \mathrm{C}$ (colorless needles from $n$-hexane). $[\alpha]_{\mathrm{D}}^{20}+22.4^{\circ}\left(c=1.4, \mathrm{CHCl}_{3}\right)$. IR (neat): $1643 \mathrm{~cm}^{-1} \cdot{ }^{1} \mathrm{H}-\mathrm{NMR}$ $\left(\mathrm{CDCl}_{3}\right) \delta: 0.84(3 \mathrm{H}, \mathrm{s}), 0.85(3 \mathrm{H}, \mathrm{s}), 0.90(3 \mathrm{H}, \mathrm{s}), 1.02-1.07(1 \mathrm{H}, \mathrm{m}), 1.11$
$(1 \mathrm{H}, \mathrm{dd}, J=12.4,2.8 \mathrm{~Hz}), 1.15-1.24(1 \mathrm{H}, \mathrm{m}), 1.34-1.44(3 \mathrm{H}, \mathrm{m}), 1.46$ $1.53(2 \mathrm{H}, \mathrm{m}), 1.63-1.74(1 \mathrm{H}, \mathrm{m}), 2.06-2.14(1 \mathrm{H}, \mathrm{m}), 2.40(1 \mathrm{H}, \mathrm{d}, J=$ $10.4 \mathrm{~Hz}), 2.45(1 \mathrm{H}$, ddd, $J=13.4,4.4,2.4 \mathrm{~Hz}), 4.53(1 \mathrm{H}, \mathrm{q}, J=2.0 \mathrm{~Hz}), 4.75$ $(1 \mathrm{H}, \mathrm{q}, J=2.0 \mathrm{~Hz}), 5.97(1 \mathrm{H}, \mathrm{dd}, J=15.8,10.0 \mathrm{~Hz}), 6.19(1 \mathrm{H}, \mathrm{d}, J=15.6 \mathrm{~Hz})$, $6.54(1 \mathrm{H}$, br s $), 7.33-7.36(2 \mathrm{H}, \mathrm{m}) .{ }^{13} \mathrm{C}-\mathrm{NMR} \delta$ : 15.0, 19.1, 22.0, 23.4, 33.6 (2C), 36.8, 39.1, 40.8, 42.3, 54.8, 61.5, 107.6, 108.0, 121.7, 124.5, 128.3 139.6, 143.2, 150.2. HR-MS (EI) Calcd for $\mathrm{C}_{20} \mathrm{H}_{28} \mathrm{O}_{2}: 284.2140$. Found: 284.2138

(+)-(5S,9S,10S)-15,16-Epoxy-8(17),13(16),14-labdatriene (13) A mixture of $(+)-12(0.300 \mathrm{~g}, 1.05 \mathrm{mmol})$, quinoline $(0.05 \mathrm{~g}, 0.38 \mathrm{mmol})$ and $5 \%$ $\mathrm{Pd}-\mathrm{BaSO}_{4}(0.200 \mathrm{~g})$ in $\mathrm{MeOH}(10.0 \mathrm{ml})$ was subjected to hydrogenation under hydrogen atmosphere for $3 \mathrm{~d}$ at ordinary temperature. The reaction mixture was filtered with the aid of celite and filtrate was condensed to give a residue which was chromatographed on silica gel (20.0 g, $n$-hexane) to provide $(+)-13(0.259 \mathrm{~g}, 86 \%)$ as a colorless oil. $(+)-13:[\alpha]_{\mathrm{D}}^{23}+44.1^{\circ}$ $\left(c=0.59, \mathrm{CHCl}_{3}\right)$. IR (neat): $1644,1564,1496 \mathrm{~cm}^{-1} \cdot{ }^{1} \mathrm{H}-\mathrm{NMR}\left(\mathrm{CDCl}_{3}\right) \delta$ : $0.69(3 \mathrm{H}, \mathrm{s}), 0.80(3 \mathrm{H}, \mathrm{s}), 0.86(3 \mathrm{H}, \mathrm{s}), 0.97(1 \mathrm{H}, \mathrm{dd}, J=12.6,4.0 \mathrm{~Hz}), 1.07$ $(1 \mathrm{H}, \mathrm{dd}, J=12.8,2.8 \mathrm{~Hz}), 1.16(1 \mathrm{H}, \mathrm{dd}, J=13.2,4.0 \mathrm{~Hz}), 1.29-1.53(3 \mathrm{H}$, m), $1.54-1.66(3 \mathrm{H}, \mathrm{m}), 1.69-1.79(3 \mathrm{H}, \mathrm{m}), 1.97(1 \mathrm{H}, \mathrm{ddd}, J=12.8,12.8$, $5.2 \mathrm{~Hz}), 2.19-2.28(1 \mathrm{H}, \mathrm{m}), 2.40(1 \mathrm{H}, \mathrm{ddd}, J=12.6,3.8,2.0 \mathrm{~Hz}), 2.55(1 \mathrm{H}$, ddd, $J=14.0,10.0,2.8 \mathrm{~Hz}), 4.56(1 \mathrm{H}, \mathrm{s}), 4.86(1 \mathrm{H}, \mathrm{s}), 6.26(1 \mathrm{H}, \mathrm{br} \mathrm{s}), 7.19$ $(1 \mathrm{H}$, brs $), 7.34(1 \mathrm{H}$, brs $) .{ }^{13} \mathrm{C}-\mathrm{NMR} \delta: 14.5,19.4,21.7,23.6,24.0,24.4$, 33.6 (2C), 38.3, 39.0, 39.6, 42.1, 55.5, 56.1, 106.2, 111.0, 125.6, 138.7, 142.6, 148.5. HR-MS (EI) Calcd for $\mathrm{C}_{20} \mathrm{H}_{30} \mathrm{O}_{2}: 286.2297$. Found: 286.2300.

(+)-Austrochaparol (3) To a solution of $(+)-13(0.050 \mathrm{~g}, 0.175 \mathrm{mmol})$ in $\mathrm{CH}_{2} \mathrm{Cl}_{2}(1.50 \mathrm{ml})$ was added $\mathrm{SeO}_{2}(0.160 \mathrm{~g}, 1.43 \mathrm{mmol})$ at $0{ }^{\circ} \mathrm{C}$ and the whole mixture was stirred for $12 \mathrm{~h}$ at $\mathrm{rt}$. The reaction mixture was diluted with saturated $\mathrm{Na}_{2} \mathrm{~S}_{2} \mathrm{O}_{3}$ and extracted with AcOEt. The organic layer was washed with brine and dried over $\mathrm{MgSO}_{4}$. Removal of the organic solvent gave a crude residue, which was chromatographed on silica gel $(5.00 \mathrm{~g}, n$ hexane : $\mathrm{AcOEt}=10: 1)$ to afford $(+)-3(0.026 \mathrm{~g}, 50 \%)$ as a colorless oil $(+)-3:[\alpha]_{\mathrm{D}}^{27}+5.6^{\circ}\left(c=0.50, \mathrm{CHCl}_{3}\right) . \quad \mathrm{IR}(\mathrm{KBr}): 3330 \mathrm{~cm}^{-1} \cdot{ }^{1} \mathrm{H}-\mathrm{NMR}$ $\left(\mathrm{CDCl}_{3}\right) \delta: 0.67(3 \mathrm{H}, \mathrm{s}), 0.80(3 \mathrm{H}, \mathrm{s}), 0.88(3 \mathrm{H}, \mathrm{s}), 1.05(1 \mathrm{H}$, ddd, $J=17.0$, $13.0,4.0 \mathrm{~Hz}), 1.21(1 \mathrm{H}$, ddd, $J=17.0,13.0,4.0 \mathrm{~Hz}), 1.35-1.65(7 \mathrm{H}, \mathrm{m})$, $1.70-1.84(2 \mathrm{H}, \mathrm{m}), 1.84-1.90(1 \mathrm{H}, \mathrm{m}), 2.17(1 \mathrm{H}, \mathrm{dd}, J=10.0,1.3 \mathrm{~Hz})$ $2.20-2.29(1 \mathrm{H}, \mathrm{m}), 2.53(1 \mathrm{H}, \mathrm{ddd}, J=14.2,10.0,4.0 \mathrm{~Hz}), 4.40(1 \mathrm{H}, \mathrm{brs})$, $4.70(1 \mathrm{H}, \mathrm{dd}, J=1.3,1.1 \mathrm{~Hz}), 5.09(1 \mathrm{H}, \mathrm{dd}, J=1.1,1.1 \mathrm{~Hz}), 6.27(1 \mathrm{H}, \mathrm{d}, J=$ $1.0 \mathrm{~Hz}), 7.20(1 \mathrm{H}, \mathrm{dd}, J=1.1,1.1 \mathrm{~Hz}), 7.35(1 \mathrm{H}, \mathrm{dd}, J=1.6,1.6 \mathrm{~Hz}) .{ }^{13} \mathrm{C}-$ NMR $\delta: 13.5,19.4,21.5,23.4,23.7,31.0,33.1,33.3,38.8,39.8,42.1,47.6$, 50.4, 74.2, 109.7, 110.9, 125.4, 138.7, 142.7, 149.6. HR-MS (EI) Calcd for $\mathrm{C}_{20} \mathrm{H}_{30} \mathrm{O}_{2}: 302.2246$. Found: 302.2244 .

(-)-epi-Coronarin A (14) To a solution of (+)-2 $(0.050 \mathrm{~g}, 0.176 \mathrm{mmol})$ in $\mathrm{CH}_{2} \mathrm{Cl}_{2}(1.50 \mathrm{ml})$ was added $\mathrm{SeO}_{2}(0.039 \mathrm{~g}, 0.252 \mathrm{mmol})$ at $0{ }^{\circ} \mathrm{C}$ and the whole mixture was stirred for $30 \mathrm{~min}$ at $0{ }^{\circ} \mathrm{C}$. The reaction mixture was diluted with brine and extracted with $\mathrm{CH}_{2} \mathrm{Cl}_{2}$. The organic layer was dried over $\mathrm{MgSO}_{4}$. Removal of the organic solvent gave a crude residue, which was chromatographed on silica gel $(5.00 \mathrm{~g}, n$-hexane : AcOEt $=20: 1)$ to afford $(-)-14(0.025 \mathrm{~g}, 47 \%)$ as a colorless oil. $(-)-14:[\alpha]_{\mathrm{D}}^{23}-13.4^{\circ}(c=1.16$ $\left.\mathrm{CHCl}_{3}\right)$. IR (neat): $3390,1647 \mathrm{~cm}^{-1} .{ }^{1} \mathrm{H}-\mathrm{NMR}\left(\mathrm{CDCl}_{3}\right) \delta: 0.81(3 \mathrm{H}, \mathrm{s}), 0.83$ $(3 \mathrm{H}, \mathrm{s}), 0.90(3 \mathrm{H}, \mathrm{s}), 1.03-1.13(1 \mathrm{H}, \mathrm{m}), 1.16-1.28(2 \mathrm{H}, \mathrm{m}), 1.37-1.67$ $(6 \mathrm{H}, \mathrm{m}), 1.81-1.91(1 \mathrm{H}, \mathrm{m}), 2.88(1 \mathrm{H}, \mathrm{d}, J=10.0 \mathrm{~Hz}), 4.38-4.42(1 \mathrm{H}, \mathrm{m})$, $4.69(1 \mathrm{H}, \mathrm{dd}, J=1.6,1.6 \mathrm{~Hz}), 4.98(1 \mathrm{H}, \mathrm{dd}, J=1.6,1.6 \mathrm{~Hz}), 5.90(1 \mathrm{H}, \mathrm{dd}, J=$ $15.8,10.0 \mathrm{~Hz}), 6.24(1 \mathrm{H}, \mathrm{d}, J=15.8 \mathrm{~Hz}), 6.50-6.53(1 \mathrm{H}, \mathrm{m}), 7.31-7.37$ $(2 \mathrm{H}, \mathrm{m}) .{ }^{13} \mathrm{C}-\mathrm{NMR} \delta$ : 14.0, 19.0, 21.7, 30.0, 33.1, 33.2, 39.4, 40.4, 42.2, 46.9, 56.0, 73.4, 107.5, 111.8, 122.4, 124.3, 127.2, 139.7, 143.3, 151.3. HRMS (EI) Calcd for $\mathrm{C}_{20} \mathrm{H}_{28} \mathrm{O}_{2}: 300.2089$. Found: 300.2082 .

(+)-Coronarin A (1) To a solution of $(-)-14(0.009 \mathrm{~g}, 0.03 \mathrm{mmol})$ in $\mathrm{CH}_{2} \mathrm{Cl}_{2}(1.00 \mathrm{ml})$ was added Dess-Martin reagent $(0.038 \mathrm{~g}, 0.09 \mathrm{mmol})$ at $0{ }^{\circ} \mathrm{C}$ and the whole mixture was stirred for $1 \mathrm{~h}$ at the same temperature. The reaction mixture was filtered and the filtrate was condensed to give a crude 15, which was used for the next reaction without further purification. To a solution of the above 15 in $\mathrm{MeOH}(1.00 \mathrm{ml})$ was added $\mathrm{NaBH}_{4}(0.001 \mathrm{~g}$, $0.03 \mathrm{mmol}$ ) at $0{ }^{\circ} \mathrm{C}$ and the whole mixture was stirred for $20 \mathrm{~min}$ at the same temperature. The reaction mixture was diluted with saturated $\mathrm{NaHCO}_{3}$ and extracted with $\mathrm{Et}_{2} \mathrm{O}$. The organic layer was dried over $\mathrm{MgSO}_{4}$. Removal of the organic solvent gave a residue, which was chromatographed on silica ge $(3.00 \mathrm{~g}, n$-hexane : $\mathrm{AcOEt}=20: 1)$ to provide $(+)-\mathbf{1}(0.007 \mathrm{~g}, 78 \%)$ as a colorless oil. $(+)-\mathbf{1}: \operatorname{mp} 99-101^{\circ} \mathrm{C}$ (colorless needles from $n$-hexane), $[\alpha]_{\mathrm{D}}^{23}$ $+26.9^{\circ}\left(c=0.35, \mathrm{CHCl}_{3}\right)$. IR (neat): $3351,1650 \mathrm{~cm}^{-1} .{ }^{1} \mathrm{H}-\mathrm{NMR}\left(\mathrm{CDCl}_{3}\right) \delta$ : $0.85(3 \mathrm{H}, \mathrm{s}), 0.85(3 \mathrm{H}, \mathrm{s}), 0.93(3 \mathrm{H}, \mathrm{s}), 0.93-1.04(1 \mathrm{H}, \mathrm{m}), 1.13-1.56$ $(7 \mathrm{H}, \mathrm{m}), 1.82(1 \mathrm{H}$, br s $), 2.10(1 \mathrm{H}, \mathrm{ddd}, J=12.0,5.6,2.4 \mathrm{~Hz}), 2.35(1 \mathrm{H}, \mathrm{d}$, $J=9.6 \mathrm{~Hz}), 4.10(1 \mathrm{H}, \mathrm{dd}, J=11.2,5.6 \mathrm{~Hz}), 4.74(1 \mathrm{H}, \mathrm{s}), 5.13(1 \mathrm{H}, \mathrm{s}), 5.99$ $(1 \mathrm{H}, \mathrm{dd}, J=15.6,9.6 \mathrm{~Hz}), 6.21(1 \mathrm{H}, \mathrm{d}, J=15.6 \mathrm{~Hz}), 6.55(1 \mathrm{H}, \mathrm{s}), 7.37(2 \mathrm{H}$, m). ${ }^{13} \mathrm{C}$-NMR $\delta$ : $15.0,19.0,21.9,33.1,33.5$ (2C), 39.1, 40.3, 42.0, 52.5, 
59.7, 73.3, 104.8, 107.6, 122.2, 124.3, 126.9, 139.8, 143.3, 152.1. HR-MS (EI) Calcd for $\mathrm{C}_{20} \mathrm{H}_{28} \mathrm{O}_{2}: 300.2089$. Found: 300.2080 .

(+)-(1R,4aS,8aS)-Decahydro-5,5,8a-trimethyl-2-methylene-1-naphthaleneacetonitrile (16) To a solution of $(+)-5(0.60 \mathrm{~g}, 2.7 \mathrm{mmol})$ in toluene $(10 \mathrm{ml})$ was added acetone cyanohydrin $(2.5 \mathrm{ml}, 27 \mathrm{mmol}), \mathrm{Ph}_{3} \mathrm{P}$ $(1.1 \mathrm{~g}, 4.1 \mathrm{mmol})$ and diisopropylazodicarboxylate (DIAD, $0.8 \mathrm{ml}, 4.1 \mathrm{mmol})$ and the mixture was stirred for $1 \mathrm{~d}$ at $70^{\circ} \mathrm{C}$. The reaction mixture was diluted with water (ice) and extracted with AcOEt. The organic layer was washed with brine and dried over $\mathrm{MgSO}_{4}$. Evaporation of the organic solvent gave a crude oil, which was chromatographed on silica gel $(40 \mathrm{~g}, \mathrm{n}$ hexane : $\mathrm{AcOEt}=19: 1)$ to afford a nitrile $(16)(0.400 \mathrm{~g}, 64 \%)$ as colorless plates ( $n$-hexane). ${ }^{1} \mathrm{H}$ - and ${ }^{13} \mathrm{C}$-NMR data of the synthetic $\mathbf{1 6}$ were identical with those of the reported $(+)-16{ }^{15)}$

$(+)-(1 R, 3 S, 4 \mathrm{a} S, 8 \mathrm{a} S)$-Decahydro-5,5,8a-trimethyl-3-hydroxy-2-methylene-1-naphthaleneacetonitrile (17) $\mathrm{To}$ a solution of $\mathrm{SeO}_{2}(0.111 \mathrm{~g}$, $1 \mathrm{mmol})$ in $\mathrm{CH}_{2} \mathrm{Cl}_{2}(5 \mathrm{ml})$ was added $5.5 \mathrm{M}$ tert-BuOOH in decane solution $(0.73 \mathrm{ml}, 4 \mathrm{mmol})$ and the mixture was stirred for $1 \mathrm{~h}$ at $\mathrm{rt}$. A solution of 16 $(0.462 \mathrm{~g}, 2 \mathrm{mmol})$ in $\mathrm{CH}_{2} \mathrm{Cl}_{2}(1 \mathrm{ml})$ was added to the above solution and the whole mixture was stirred for $1 \mathrm{~d}$ at $\mathrm{rt}$. The reaction mixture was diluted with saturated $\mathrm{Na}_{2} \mathrm{~S}_{2} \mathrm{O}_{3}$ solution and extracted with AcOEt. The organic layer was washed with brine and dried over $\mathrm{MgSO}_{4}$. The organic layer was evaporated to give a crude residue, which was chromatographed on silica gel (40 g, $n$-hexane : $\mathrm{AcOEt}=3: 1)$ to afford $(-)-17(0.392 \mathrm{~g}, 79 \%)$. Recrystallization of (-)-17 from $n$-hexane gave colorless needles. (-)-17: $\mathrm{mp} 149$ $150^{\circ} \mathrm{C} ;[\alpha]_{\mathrm{D}}^{23}-24.9^{\circ}\left(c=0.83, \mathrm{CHCl}_{3}\right)$; IR $(\mathrm{KBr}): 3445,2259 \mathrm{~cm}^{-1} ;{ }^{1} \mathrm{H}-$ NMR $\delta: 0.67(3 \mathrm{H}, \mathrm{s}), 0.82(3 \mathrm{H}, \mathrm{s}), 0.91(3 \mathrm{H}, \mathrm{s}), 1.18-1.29(2 \mathrm{H}, \mathrm{m}), 1.38$ $1.48(1 \mathrm{H}, \mathrm{m}), 1.51-1.62(5 \mathrm{H}, \mathrm{m}), 1.71(1 \mathrm{H}, \mathrm{dd}, J=13.6,3.0 \mathrm{~Hz}), 1.91(1 \mathrm{H}$ ddd, $J=13.6,2.5,2.5 \mathrm{~Hz}), 2.30(1 \mathrm{H}, \mathrm{dd}, J=16.6,10.8 \mathrm{~Hz}), 2.58(1 \mathrm{H}, \mathrm{dd}, J=$ $16.6,3.8 \mathrm{~Hz}), 2.73(1 \mathrm{H}, \mathrm{ddd}, J=19.9,1.9,2.0 \mathrm{~Hz}), 4.43(1 \mathrm{H}, \mathrm{br} \mathrm{s}), 4.77(1 \mathrm{H}$ d, $J=1.8 \mathrm{~Hz}), 5.18(1 \mathrm{H}, \mathrm{d}, J=1.5 \mathrm{~Hz}) \cdot{ }^{13} \mathrm{C}-\mathrm{NMR} \delta: 13.0,13.8,19.2,21.6$, $30.3,33.1,33.3,38.9,39.6,41.8,47.2,47.9,73.2,110.6,119.8,147.8$. MS (FAB) $m / z: 248\left(\mathrm{M}^{+}+1\right), 230\left(\mathrm{M}^{+}+1-\mathrm{H}_{2} \mathrm{O}\right)$

$(+)-(1 R, 3 R, 4 \mathrm{a} S, 8 \mathrm{a} S)$-Decahydro-5,5,8a-trimethyl-3-benzoyloxy-2methylene-1-naphthaleneacetonitrile (18) To a solution of (-)-17 $(0.209 \mathrm{~g}, 0.84 \mathrm{mmol})$ in THF $(6 \mathrm{ml})$ was added benzoic acid $(0.642 \mathrm{~g}$, $5.3 \mathrm{mmol}), \mathrm{Ph}_{3} \mathrm{P}(1.324 \mathrm{~g}, 5.1 \mathrm{mmol})$ and $49 \%$ diethylazodicarboxylate in toluene solution $(2.2 \mathrm{ml}, 5.1 \mathrm{mmol})$ at $0{ }^{\circ} \mathrm{C}$ and the whole mixture was stirred for $1 \mathrm{~h}$ at $0{ }^{\circ} \mathrm{C}$. The reaction mixture was diluted with $7 \%$ aqueous $\mathrm{NaHCO}_{3}$ and extracted with $\mathrm{Et}_{2} \mathrm{O}$. The organic layer was washed with brine, and dried over $\mathrm{MgSO}_{4}$. The organic layer was evaporated to give a crude residue, which was chromatographed on silica gel ( $40 \mathrm{~g}, n$-hexane : $\mathrm{AcOEt}=5: 1)$ to afford $(+)-\mathbf{1 8}(0.234 \mathrm{~g}, 79 \%)$ as colorless prisms $(n-$ hexane/AcOEt). $(+)-18: \mathrm{mp} 150-151^{\circ} \mathrm{C} ;[\alpha]_{\mathrm{D}}^{25}+89.7^{\circ}\left(c=0.95, \mathrm{CHCl}_{3}\right)$ IR (KBr): $3349 \mathrm{~cm}^{-1} ;{ }^{1} \mathrm{H}-\mathrm{NMR} \delta: 0.78(3 \mathrm{H}, \mathrm{s}), 0.85(3 \mathrm{H}, \mathrm{s}), 0.94(3 \mathrm{H}, \mathrm{s})$, $1.16-1.29(3 \mathrm{H}, \mathrm{m}), 1.32(1 \mathrm{H}, \mathrm{dd}, J=13.1,2.5 \mathrm{~Hz}), 1.45-1.68(4 \mathrm{H}, \mathrm{m})$, $2.18-2.27(2 \mathrm{H}, \mathrm{m}), 2.44(1 \mathrm{H}, \mathrm{dd}, J=16.6,10.0 \mathrm{~Hz}), 2.61(1 \mathrm{H}, \mathrm{dd}, J=16.6$, $4.6 \mathrm{~Hz}), 4.82(1 \mathrm{H}, \mathrm{br} \mathrm{s}), 5.31(1 \mathrm{H}, \mathrm{br} \mathrm{s}), 5.46(1 \mathrm{H}, \mathrm{dd}, J=16.6,5.5 \mathrm{~Hz}), 7.47$ $(2 \mathrm{H}, \mathrm{t}, J=7.6 \mathrm{~Hz}), 7.59(1 \mathrm{H}, \mathrm{t}, J=7.5 \mathrm{~Hz}), 8.13(2 \mathrm{H}, \mathrm{d}, J=7.7 \mathrm{~Hz}) .{ }^{13} \mathrm{C}-\mathrm{NMR}$ $\delta: 13.9,14.0,19.1,21.7,30.1,33.5,33.6,39.0,39.2,41.6,51.5,52.4,74.3$, 105.7, 119.3, 128.3 (2C), 129.5 (2C), 130.1, 132.9, 143.8, 165.0. Anal. Calcd for $\mathrm{C}_{23} \mathrm{H}_{29} \mathrm{NO}_{2}$ : C, 78.59; H, 8.32; N, 3.98. Found: C, 78.39; H, 8.51; $\mathrm{N}, 3.50$. MS (FAB) $m / z: 352\left(\mathrm{M}^{+}+1\right)$.

$(+)-(1 R, 3 R, 4 \mathrm{a} S, 8 \mathrm{a} S)$-Decahydro-5,5,8a-trimethyl-3-hydroxy-2-methylene-1-naphthaleneacetonitrile (19) A mixture of (+)-18 $(0.160 \mathrm{~g}$, $0.46 \mathrm{mmol})$ and $\mathrm{K}_{2} \mathrm{CO}_{3}(0.077 \mathrm{~g}, 0.55 \mathrm{mmol})$ in $\mathrm{MeOH}(2 \mathrm{ml})$ was stirred for $3 \mathrm{~h}$ at $\mathrm{rt}$. The reaction mixture was diluted with $7 \%$ aqueous $\mathrm{NaHCO}_{3}$ and extracted with $\mathrm{Et}_{2} \mathrm{O}$. The organic layer was washed with brine, and dried over $\mathrm{MgSO}_{4}$. The organic layer was evaporated to give a crude residue, which was chromatographed on silica gel $(10 \mathrm{~g}, n$-hexane : $\mathrm{AcOEt}=5: 1)$ to afford $(+)-19(0.088 \mathrm{~g}, 78 \%)$ as colorless plates $(n$-hexane/AcOEt $) .(+)-19$ : $\mathrm{mp} 107-108^{\circ} \mathrm{C} ;[\alpha]_{\mathrm{D}}^{23}+35.3^{\circ}\left(c=0.92, \mathrm{CHCl}_{3}\right)$; IR $(\mathrm{KBr}): 3425,2260$ $\mathrm{cm}^{-1}$; ${ }^{1} \mathrm{H}-\mathrm{NMR} \delta: 0.68(3 \mathrm{H}, \mathrm{s}), 0.83(3 \mathrm{H}, \mathrm{s}), 0.93(3 \mathrm{H}, \mathrm{s}), 1.07-1.34(5 \mathrm{H}$, $\mathrm{m}), 1.43-1.49(1 \mathrm{H}, \mathrm{m}), 1.51-1.62(2 \mathrm{H}, \mathrm{m}), 1.79(1 \mathrm{H}, \mathrm{d}, J=5.0 \mathrm{~Hz})$ $2.06-2.17(2 \mathrm{H}, \mathrm{m}), 2.41(1 \mathrm{H}, \mathrm{dd}, J=16.6,10.6 \mathrm{~Hz}), 2.59(1 \mathrm{H}, \mathrm{dd}, J=16.6$, $4.0 \mathrm{~Hz}), 4.07(1 \mathrm{H}, \mathrm{dd}, J=11.0,5.0 \mathrm{~Hz}), 4.81(1 \mathrm{H}, \mathrm{br} \mathrm{s}), 5.34(1 \mathrm{H}, \mathrm{br} \mathrm{s}) .{ }^{13} \mathrm{C}-$ NMR $\delta: 13.8,13.9,19.1,21.6,33.1,33.4(2 \mathrm{C}), 38.9,39.0,41.5,51.3,52.4$, 72.8, 104.7, 119.7, 148.2. Anal. Calcd for $\mathrm{C}_{16} \mathrm{H}_{25} \mathrm{NO}: \mathrm{C}, 77.68 ; \mathrm{H}, 10.19 ; \mathrm{N}$, 5.66. Found: C, 77.71; H, 10.28; N, 5.33. MS (FAB) $m / z: 270\left(\mathrm{M}^{+}+\mathrm{Na}\right)$.

(+)-(1R,3R,4a $S, 8 \mathrm{a} S)$-Decahydro-5,5,8a-trimethyl-3-tert-butyldimethylsiloxy-2-methylene-naphthaleneacetonitrile (20) A mixture of $(+)-19(0.131 \mathrm{~g}, 0.53 \mathrm{mmol})$, tert-butyldimethylsilyl chloride (TBDMSCl $0.123 \mathrm{~g}, 0.82 \mathrm{mmol})$ and imidazole $(0.063 \mathrm{~g}, 0.92 \mathrm{mmol})$ in DMF $(1.5 \mathrm{ml})$ was stirred for $1 \mathrm{~h}$ at $\mathrm{rt}$. The reaction mixture was diluted with brine and extracted with $\mathrm{Et}_{2} \mathrm{O}$. The organic layer was dried over $\mathrm{MgSO}_{4}$. The organic layer was evaporated to give a crude residue, which was chromatographed on silica gel $(10 \mathrm{~g}, n$-hexane : $\mathrm{AcOEt}=10: 1)$ to afford $(+)-20(0.186 \mathrm{~g}$, 97\%) as colorless needles ( $n$-hexane). $(+)$-20: $\mathrm{mp} 69^{\circ} \mathrm{C} ;[\alpha]_{\mathrm{D}}^{27}+20.8^{\circ}(c=$ $\left.0.75, \mathrm{CHCl}_{3}\right)$; IR $(\mathrm{KBr}): 2245 \mathrm{~cm}^{-1} ;{ }_{1}^{1} \mathrm{H}-\mathrm{NMR} \delta: 0.09(3 \mathrm{H}, \mathrm{s}), 0.10(3 \mathrm{H}, \mathrm{s})$, $0.67(3 \mathrm{H}, \mathrm{s}), 0.82(3 \mathrm{H}, \mathrm{s}), 0.91(3 \mathrm{H}, \mathrm{s}), 0.93(9 \mathrm{H}, \mathrm{s}), 1.13(1 \mathrm{H}, \mathrm{dd}, J=12.9$, $2.3 \mathrm{~Hz}), 1.21(1 \mathrm{H}, \mathrm{dd}, J=11.9,6.3 \mathrm{~Hz}), 1.24-1.37(2 \mathrm{H}, \mathrm{m}), 1.42-1.49$ $(1 \mathrm{H}, \mathrm{m}), 1.51-1.62(2 \mathrm{H}, \mathrm{m}), 1.95(1 \mathrm{H}, \mathrm{ddd}, J=12.6,5.5,2.5 \mathrm{~Hz}), 2.03$ $2.10(1 \mathrm{H}, \mathrm{m}), 2.39(1 \mathrm{H}, \mathrm{dd}, J=16.9,10.6 \mathrm{~Hz}), 2.55(1 \mathrm{H}, \mathrm{dd}, J=16.7,4.3$ $\mathrm{Hz}), 3.98(1 \mathrm{H}, \mathrm{dd}, J=10.8,5.3 \mathrm{~Hz}), 4.73(1 \mathrm{H}, \mathrm{brs}), 5.37(1 \mathrm{H}, \mathrm{brs}) .{ }^{13} \mathrm{C}-$ NMR $\delta$ : $-4.8,-4.7,13.9,14.1,18.6,19.2,21.8,26.0$ (3C), 33.4, 33.5, 34.1, 39.1, 39.2, 41.7, 51.6, 52.6, 74.0, 105.6, 119.8, 147.8. Anal. Calcd for $\mathrm{C}_{22} \mathrm{H}_{39} \mathrm{NOSi}$ : C, 73.07; H, 10.87; N, 3.87. Found: C, 73.04; H, 11.02; N, 3.64. MS (FAB) $m / z: 384\left(\mathrm{M}^{+}+\mathrm{Na}\right)$.

$(-)-(1 R, 3 R, 4 \mathrm{a} S, 8 \mathrm{a} S)$-Decahydro-5,5,8a-trimethyl-3-tert-butyldimethylsiloxy-2-methylene-naphthaleneacetoaldehyde (21) To a solution of $(+)-20(0.185 \mathrm{~g}, 0.51 \mathrm{mmol})$ in toluene $(1.5 \mathrm{ml})$ was added $1 \mathrm{M} \mathrm{di}-$ isobutylaluminum hydride (Dibal) in toluene solution $(0.6 \mathrm{ml}, 0.6 \mathrm{mmol})$ at $-78^{\circ} \mathrm{C}$ and the reaction mixture was stirred for $30 \mathrm{~min}$ at at $-78^{\circ} \mathrm{C}$. To the reaction mixture was added acetone $(0.2 \mathrm{ml})$ at $0^{\circ} \mathrm{C}$. The reaction mixture was acidified with $2 \mathrm{M} \mathrm{HCl}$ solution and extracted with $\mathrm{Et}_{2} \mathrm{O}$. The organic layer was washed with brine, and dried over $\mathrm{MgSO}_{4}$. The organic layer was evaporated to give a crude residue, which was chromatographed on silica gel $(10 \mathrm{~g}, n$-hexane : $\mathrm{AcOEt}=20: 1)$ to afford $(-)-21(0.163 \mathrm{~g}, 87 \%)$ as a colorless oil. $(-)-21$ : $[\alpha]_{\mathrm{D}}^{24}-14.7^{\circ}\left(c=1.02, \mathrm{CHCl}_{3}\right)$; IR $(\mathrm{KBr}): 1726 \mathrm{~cm}^{-1} ;{ }^{1} \mathrm{H}-$ NMR $\delta: 0.069(3 \mathrm{H}, \mathrm{s}), 0.076(3 \mathrm{H}, \mathrm{s}), 0.70(3 \mathrm{H}, \mathrm{s}), 0.82(3 \mathrm{H}, \mathrm{s}), 0.91(3 \mathrm{H}$, s), $0.93(9 \mathrm{H}, \mathrm{s}), 1.00-1.09(1 \mathrm{H}, \mathrm{m}), 1.14-1.27(1 \mathrm{H}, \mathrm{m}), 1.28-1.40(1 \mathrm{H}$, $\mathrm{m}), 1.40-1.61(3 \mathrm{H}, \mathrm{m}), 1.96(1 \mathrm{H}$, ddd, $J=12.6,5.5,2.0 \mathrm{~Hz}), 2.27(1 \mathrm{H}, \mathrm{dd}$, $J=10.6,4.0 \mathrm{~Hz}), 2.45(1 \mathrm{H}$, ddd, $J=16.6,4.0,1.0 \mathrm{~Hz}), 2.55(1 \mathrm{H}$, ddd, $J=16.9,10.6,3.0 \mathrm{~Hz}), 3.98(1 \mathrm{H}, \mathrm{dd}, J=11.1,5.5 \mathrm{~Hz}), 4.54(1 \mathrm{H}, \mathrm{br} \mathrm{s}), 5.24$ $\left(1 \mathrm{H}\right.$, br s), $9.63(1 \mathrm{H}, \mathrm{dd}, J=3.5,1.0 \mathrm{~Hz}){ }^{13} \mathrm{C}-\mathrm{NMR} \delta:-4.8,-4.7,14.7$, $18.6,19.4,21.8,26.0$ (3C), 33.5 (2C), 34.3, 38.7, 39.4, 39.7, 42.0, 49.3, 53.1, 74.4, 105.8, 149.8, 202.7. Anal. Calcd for $\mathrm{C}_{22} \mathrm{H}_{40} \mathrm{O}_{2} \mathrm{Si}$ : C, 72.46; $\mathrm{H}$, 11.06. Found: C, 72.39; H, 10.99. MS (FAB) $m / z: 387\left(\mathrm{M}^{+}+\mathrm{Na}\right.$ ).

Horner-Emmons Condensation of (-)-21 and Diethoxyphosphonobutyrolactone To a solution of diethoxyphosphonobutyrolactone $(0.510 \mathrm{~g}$, $2.3 \mathrm{mmol})$ in DMSO $(2.5 \mathrm{ml})$ was added $t$-BuOK $(0.213 \mathrm{~g}, 1.9 \mathrm{mmol})$ and the reaction mixture was stirred for $30 \mathrm{~min}$ at $\mathrm{rt}$. To a solution of $(-)-21$ $(0.163 \mathrm{~g}, 0.44 \mathrm{mmol})$ in DMSO $(0.5 \mathrm{ml})$ was added the above ylide solution at $\mathrm{rt}$ and the whole mixture was stirred for $30 \mathrm{~min}$ at $\mathrm{rt}$. The reaction mixture was diluted with brine and extracted with $\mathrm{Et}_{2} \mathrm{O}$. The organic layer was dried over $\mathrm{MgSO}_{4}$. The organic layer was evaporated to give a crude residue, which was chromatographed on silica gel $(15 \mathrm{~g}, n$-hexane : $\mathrm{AcOEt}=5: 1)$ to afford the less polar $(+)-22(0.053 \mathrm{~g}, 27 \%)$ as a colorless amorphous solid and the more polar $(+)-23(0.122 \mathrm{~g}, 63 \%)$ as colorless needles ( $n$-hexane). $(+)-22: \mathrm{mp} 104{ }^{\circ} \mathrm{C} ;[\alpha]_{\mathrm{D}}^{24}+21.8^{\circ}\left(c=1.0, \mathrm{CHCl}_{3}\right) ; \mathrm{IR}(\mathrm{KBr}): 1745$, $1660 \mathrm{~cm}^{-1} ;{ }^{1} \mathrm{H}-\mathrm{NMR} \delta: 0.069(3 \mathrm{H}, \mathrm{s}), 0.082(3 \mathrm{H}, \mathrm{s}), 0.72(3 \mathrm{H}, \mathrm{s}), 0.81(3 \mathrm{H}$ s), $0.88(3 \mathrm{H}, \mathrm{s}), 0.93(9 \mathrm{H}, \mathrm{s}), 1.00-1.22(3 \mathrm{H}, \mathrm{m}), 1.24-1.38(2 \mathrm{H}, \mathrm{m})$, $1.38-1.45(1 \mathrm{H}, \mathrm{m}), 1.46-1.56(1 \mathrm{H}, \mathrm{m}), 1.66(1 \mathrm{H}, \mathrm{d}, J=10.6 \mathrm{~Hz}), 1.74$ $1.81(1 \mathrm{H}, \mathrm{m}), 1.93(1 \mathrm{H}, \mathrm{ddd}, J=12.1,5.0,2.0 \mathrm{~Hz}), 2.69-2.79(1 \mathrm{H}, \mathrm{m})$, $2.84-2.91(2 \mathrm{H}, \mathrm{m}), 2.97-3.07(1 \mathrm{H}, \mathrm{m}), 3.91(1 \mathrm{H}, \mathrm{dd}, J=11.1,5.0 \mathrm{~Hz})$, $4.26-4.34(2 \mathrm{H}, \mathrm{m}), 4.52(1 \mathrm{H}, \mathrm{d}, J=1.5 \mathrm{~Hz}), 5.25(1 \mathrm{H}, \mathrm{d}, J=1.5 \mathrm{~Hz}), 6.01-$ $6.18(1 \mathrm{H}, \mathrm{m}) .{ }^{13} \mathrm{C}-\mathrm{NMR} \delta:-4.7(2 \mathrm{C}), 14.5,18.7,19.4,21.8,22.9,26.1$ (3C), 29.2, 33.5, 33.6, 34.6, 39.0, 39.4, 42.0, 53.2, 55.5, 65.3, 74.9, 105.3, 122.9, 144.6, 149.4, 170.0. Anal. Calcd for $\mathrm{C}_{26} \mathrm{H}_{44} \mathrm{O}_{3} \mathrm{Si}: \mathrm{C}, 72.17 ; \mathrm{H}, 10.25$. Found: C, 71.74; $\mathrm{H}, 10.15$. HR-MS (EI) $\mathrm{m} / \mathrm{z}$ : Calcd for $\mathrm{C}_{26} \mathrm{H}_{44} \mathrm{O}_{3} \mathrm{Si}$ : 432.3060. Found: 432.3050. (+)-23: $\mathrm{mp} 97^{\circ} \mathrm{C} ;[\alpha]_{\mathrm{D}}^{24}+7.0^{\circ}(c=1.0$, $\left.\mathrm{CHCl}_{3}\right)$; IR (KBr): $1745,1660 \mathrm{~cm}^{-1} ;{ }^{1} \mathrm{H}-\mathrm{NMR} \delta: 0.070(3 \mathrm{H}, \mathrm{s}), 0.083(3 \mathrm{H}$, s), $0.71(3 \mathrm{H}, \mathrm{s}), 0.82(3 \mathrm{H}, \mathrm{s}), 0.90(3 \mathrm{H}, \mathrm{s}), 0.93(9 \mathrm{H}, \mathrm{s}), 0.96-1.80(9 \mathrm{H}, \mathrm{m})$, $1.94(1 \mathrm{H}$, ddd, $J=12.6,5.6,2.5 \mathrm{~Hz}), 2.22-2.44(2 \mathrm{H}, \mathrm{m}), 2.80-2.96(2 \mathrm{H}$, $\mathrm{m}), 3.92(1 \mathrm{H}, \mathrm{dd}, J=11.1,5.5 \mathrm{~Hz}), 4.38(2 \mathrm{H}, \mathrm{t}-\mathrm{like}), 4.52(1 \mathrm{H}, \mathrm{d}, J=1.0 \mathrm{~Hz})$, $5.26(1 \mathrm{H}, \mathrm{d}, J=1.5 \mathrm{~Hz}), 6.68(1 \mathrm{H}$, ddd, $J=9.9,6.5,3.0 \mathrm{~Hz}) .{ }^{13} \mathrm{C}-\mathrm{NMR} \delta$ : -4.7 (2C), 14.5, 18.6, 19.4, 21.8, 24.4, 25.6, 26.1 (3C), 33.5 (2C), 34.4, $39.2,39.3,42.0,53.0,54.4,65.3,74.5,105.2,124.6,141.6,149.3,170.9$ Anal. Calcd for $\mathrm{C}_{26} \mathrm{H}_{44} \mathrm{O}_{3} \mathrm{Si}$ : C, $72.17 ; \mathrm{H}, 10.25$. Found: C, 72.10; H, 10.32 . MS (FAB) $m / z: 455\left(\mathrm{M}^{+}+\mathrm{Na}\right)$.

(+)-Pacovatinin A (4) To a solution of (+)-23 $(0.091 \mathrm{~g}, 0.21 \mathrm{mmol})$ in a mixed solvent $[\mathrm{MeOH}(2 \mathrm{ml}) / \mathrm{THF}(0.5 \mathrm{ml})]$ was added 10 -camphorsufonic acid $(\mathrm{CSA} ; 0.073 \mathrm{~g}, 0.32 \mathrm{mmol})$ at $\mathrm{rt}$ and the reaction mixture was stirred for $6 \mathrm{~h}$ rt. The reaction mixture was diluted with $7 \%$ aqueous $\mathrm{NaHCO}_{3}$ and extracted with $\mathrm{Et}_{2} \mathrm{O}$. The organic layer was washed with brine, and dried over $\mathrm{MgSO}_{4}$. The organic layer was evaporated to give a crude residue, which was chromatographed on silica gel $(5 \mathrm{~g}, n$-hexane : $\mathrm{AcOEt}=2: 1)$ to afford $(+)-4(0.062 \mathrm{~g}, 92 \%)$ as a colorless amorphous solid. (+)-4: $\mathrm{mp} 146$ $147^{\circ} \mathrm{C} ;[\alpha]_{\mathrm{D}}^{24}+12.8^{\circ}\left(c=1.0, \mathrm{CHCl}_{3}\right) ; \mathrm{IR}(\mathrm{KBr}): 3266,1747,1677 \mathrm{~cm}^{-1}$; 
${ }^{1} \mathrm{H}-\mathrm{NMR} \delta: 0.72(3 \mathrm{H}, \mathrm{s}), 0.83(3 \mathrm{H}, \mathrm{s}), 0.92(3 \mathrm{H}, \mathrm{s}), 1.05(1 \mathrm{H}, \mathrm{ddd}, J=12.6$, $12.6,4.0 \mathrm{~Hz}), 1.17(1 \mathrm{H}, \mathrm{dd}, J=12.6,2.5 \mathrm{~Hz}), 1.21-1.35(2 \mathrm{H}, \mathrm{m}), 1.41-$ $1.48(1 \mathrm{H}, \mathrm{m}), 1.48-1.64(2 \mathrm{H}, \mathrm{m}), 1.71(1 \mathrm{H}, \mathrm{brd}, J=5.0 \mathrm{~Hz}), 1.80(1 \mathrm{H}, \mathrm{brd}$, $J=8.1 \mathrm{~Hz}), 2.11(1 \mathrm{H}$, ddd, $J=11.6,5.6,2.5 \mathrm{~Hz}), 2.23-2.34(1 \mathrm{H}, \mathrm{m}), 2.35-$ $2.45(1 \mathrm{H}, \mathrm{m}), 2.84-2.92(2 \mathrm{H}, \mathrm{m}), 4.00(1 \mathrm{H}, \mathrm{ddd}, J=10.8,5.3,5.3 \mathrm{~Hz}), 4.39$ $(2 \mathrm{H}, \mathrm{t}-\mathrm{like}), 4.52(1 \mathrm{H}, \mathrm{br} \mathrm{s}), 5.20(1 \mathrm{H}, \mathrm{br} \mathrm{s}), 6.68(1 \mathrm{H}, \mathrm{ddd}, J=10.1,6.8$, $3.0 \mathrm{~Hz}) .{ }^{13} \mathrm{C}-\mathrm{NMR} \delta: 14.3,19.3,21.6,25.2,25.2,33.5,33.5,33.5,39.1$, 39.2, 41.8, 53.0, 54.4, 65.3, 73.6, 104.2, 124.9, 141.5, 150.1, 171.2. Anal. Calcd for $\mathrm{C}_{20} \mathrm{H}_{30} \mathrm{O}_{3} \cdot 0.5 \mathrm{H}_{2} \mathrm{O}: \mathrm{C}, 73.36 ; \mathrm{H}, 9.54$. Found: $\mathrm{C}, 73.87 ; \mathrm{H}, 9.24$ HR-MS (EI) $\mathrm{m} / z$ : Calcd for $\mathrm{C}_{20} \mathrm{H}_{30} \mathrm{O}_{3}: 318.2195$. Found: 318.2198 .

\section{References and Notes}

1) Itokawa H., Morita H., Katou I., Takya K., Cavalheiro A. J., de Oliveira R. C. B., Ishige M., Motidome M., Planta Medica, 1988, $311-315$ (1988)

2) Itokawa H., Morita H., Takya K., Motidome M., Chem. Pharm. Bull., 36, 2682-2684 (1988).

3) Bohlmann F., Zdero C., Gupta R. K., King R. M., Robinson H., Phytochemistry, 19, 2695-2705 (1980).

4) Sekiguchi M., Shigenori H., Ohsaki A., Kobayashi J., J. Nat. Prod., 64, 1102-1106 (2001).
5) Amano Y., Kinoshita M., Akita H., J. Mol. Catalysis B: Enzymatic, 32, $141-148$ (2005).

6) Oh S., Jeong I. H., Shin W-S., Lee S., Bioorg. Med. Chem. Lett., 13, 2009-2012 (2003).

7) Review: Blakemore P. R., J. Chem. Soc. Perkin Trans. 1, 2002, 25632585 (2002).

8) Maria K., Maria L., Valentine R., Tetrahedron, 61, 2003-2010 (2005).

9) Jung M., Ko I., Lee S., J. Nat. Prod., 61, 1394-1396 (1998).

10) Akita H., Amano Y., Kato K., Nozawa M., Tetrahedron: Asymmetry, 15, 725-732 (2004).

11) Matsuda H., Morikawa T., Sakamoto Y., Toguchida I., Yoshikawa M., Heterocycles, 56, 45-56 (2002).

12) Morikawa T., Matsuda H., Sakamoto Y., Ueda K., Yoshikawa M., Chem. Pharm. Bull., 50, 1045-1049 (2002).

13) Tsunoda T., Uemoto K., Nagin C., Kawamura M., Kaku H., Ito S., Tetrahedron Lett., 40, 7355-7358 (1999).

14) Micheal T. C., Franck C., J. Am. Chem. Soc., 128, 3128-3129 (2006).

15) Kinoshita M., Ohtsuka M., Nakamura D., Akita H., Chem. Pharm. Bull., 50, 930-934 (2002).

16) Mitsunobu O., Synthesis, 1981, 1-28 (1981). 